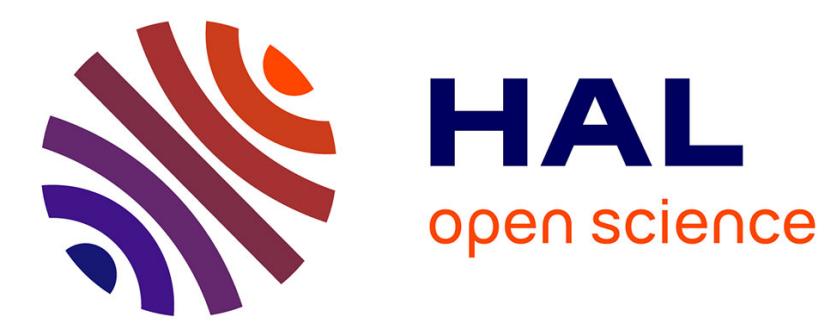

\title{
STRAIN RATE DEPENDENCE ON MECHANICAL PROPERTIES IN SOME COMMERCIAL ALUMINUM ALLOYS
}

K. Higashi, T. Mukai, K. Kaizu, S. Tsuchida, S. Tanimura

\section{- To cite this version:}

K. Higashi, T. Mukai, K. Kaizu, S. Tsuchida, S. Tanimura. STRAIN RATE DEPENDENCE ON MECHANICAL PROPERTIES IN SOME COMMERCIAL ALUMINUM ALLOYS. Journal de Physique IV Proceedings, 1991, 01 (C3), pp.C3-341-C3-346. 10.1051/jp4:1991349 . jpa-00250493

\section{HAL Id: jpa-00250493 https://hal.science/jpa-00250493}

Submitted on 1 Jan 1991

HAL is a multi-disciplinary open access archive for the deposit and dissemination of scientific research documents, whether they are published or not. The documents may come from teaching and research institutions in France or abroad, or from public or private research centers.
L'archive ouverte pluridisciplinaire HAL, est destinée au dépôt et à la diffusion de documents scientifiques de niveau recherche, publiés ou non, émanant des établissements d'enseignement et de recherche français ou étrangers, des laboratoires publics ou privés. 


\title{
STRAIN RATE DEPENDENCE ON MECHANICAL PROPERTIES IN SOME COMMERCIAL
} ALUMINUM ALLOYS

\author{
K. HIGASHI*, T. MUKAI*, K. KAIZU* ${ }^{*}$, S. TSUCHIDA* ${ }^{*}$ and S. TANIMURA** \\ *Department of Mechanical Engineering, College of Engineering, \\ University of Osaka Prefecture, Mozu-umemachi, \\ Sakai, Osaka 591, Japan \\ * Technical Research Laboratories, Sumitomo Light Metal \\ Industries, Ltd, Nagoya, Aichi, Japan
}

\begin{abstract}
La contrainte d'écoulement et la ductilité de certains alliages d'aluminium $(1050,3003,3004,5182$ et 7N01) ont été déterminées en fonction de la vitesse de déformation entre $10^{-3} \mathrm{~s}^{-1}$ et $4 \cdot 10^{3} \mathrm{~s}^{-1}$ à température ambiante. La contrainte d'écoulement maximum des alliages 1050 et 3003 augmente avec la vitesse de déformation, alors que celle des alliages 3004, 5182 et 7 N01 diminue quand la vitesse de déformation augmente dans le domaine de $10^{-3} \mathrm{~s}^{-1}$ à $10^{2} \mathrm{~s}^{-1}$. Ces trois derniers alliages, montrant un comportement particulier, contiennent des atomes de magnésium en solution. L'évolution de la contrainte d'écoulement de ces alliages semble influencée par l'intéraction entre les atomes de magnésium et les dislocations. l'allongement à la rupture augmente avec la vitesse de déformation pour tous ces alliages, sauf pour le $7 \mathrm{~N} 01$.
\end{abstract}

Abstract - The flow stress and ductility of some commercial aluminum alloys $(1050,3003,3004,5182$ and $7 N 01)$ have been investigated as a function of strain rates over the range from $1 \times 10^{-3}$ to $4 \times 10^{3} \mathrm{~s}^{-1}$ at room temperature. The maximum flow stress of both 1050 and 3003 alloys increases with increasing strain rate, but the maximum flow stress of 3004, 5182 and 7NO1 alloy decreases with increasing strain rate in the low and intermediate ranges from $1 \times 10^{-3}$ to $1 \times 10^{2} \mathrm{~s}^{-1}$. The above three alloys which showed the particular behavior of flow stress in this strain rate range contain magnesium atoms in solute. So, this behavior of flow stress in these alloys seemed to be concerned with the interaction between magnesium atoms in solute and dislocations. The elongation in failure increases with strain rate for most of the present alloys except for the 7NO1 alloy.

\section{1-INTRODUCTION}

Recently many kinds of commercial aluminum alloys have been used in press forming, and the forming rates in use are in the strain rate range from 1 to $100 \mathrm{~s}^{-1}$. Therefore, the investigation of the mechanical properties of commercial aluminum alloys in these forming rates is important to use these alloys appropriately.

It is well known that the change of flow stress of aluminum[1] and aluminum alloys[2] with strain rate at room temperature is negligible in a low strain rate range below $10^{-1} \mathrm{~s}^{-1}$; but the flow stress increases rapidly with strain rate in high strain rate ranges over $10^{3} \mathrm{~s}^{-1}$. A few reports about mechanical properties for aluminum alloys, however, were made for the strain rate ranges from $10^{-1} \mathrm{~s}^{-1}$ to $10^{2} \mathrm{~s}^{-1}[3]$. Therefore, the flow stress and ductility of some commercial aluminum alloys(1050, 3003, 3004, 5182 and 7NO1) have been investigated as a function of strain rates over the range from $1 \times 10^{-3}$ to $4 \times 10^{3}$ $\mathrm{s}^{-1}$ at room temperature. 


\section{2-EXPERIMENTAL PROCEDURE}

The chemical composition of the commercial aluminum alloys used in this study is given in Table 1. Tensile specimens, machined from hot rolled plates, had their tensile axes normal to the rolling direction. The gauge length of the specimen is 4.5 $\mathrm{mm}$ and the diameter is $3 \mathrm{~mm}$. All specimens were heated to $643 \mathrm{~K}$ with a heating rate of $47 \mathrm{~K} /$ hour and then annealed for 2 hours in air. The optical microstructures of these alloys after annealing are shown in Fig. 1 (a) (e) respectively. The grains were elongated to the direction of rolling and fiber-structures are observed for all alloys.

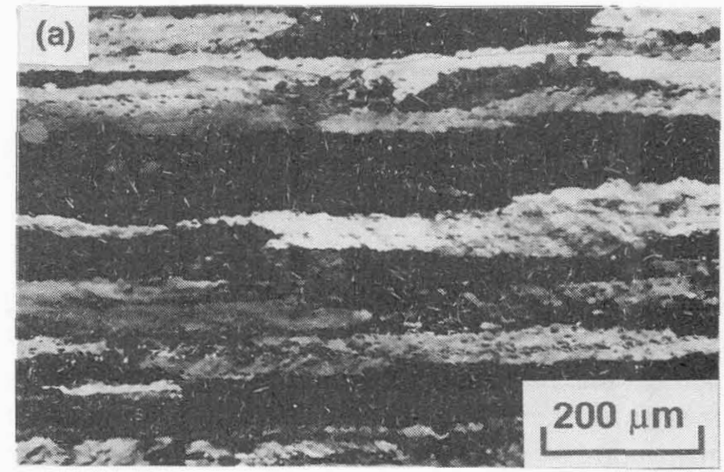

(a) 1050 alloy

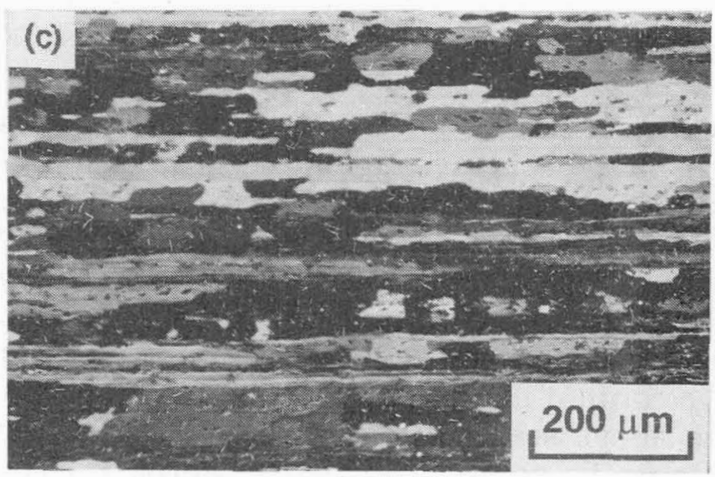

(c) 3004 alloy

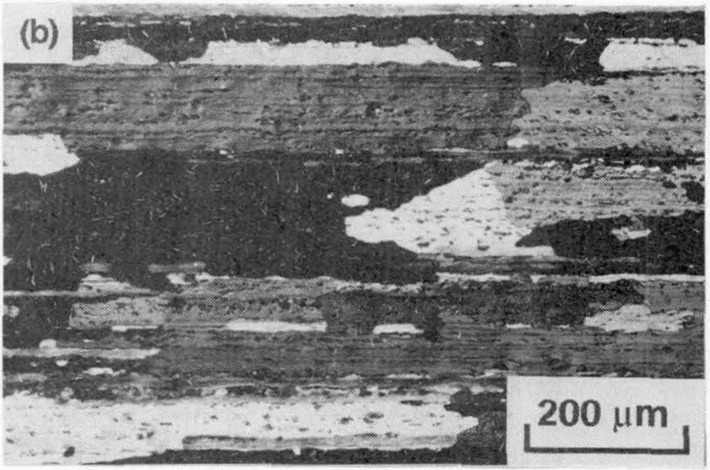

(b) 3003 alloy

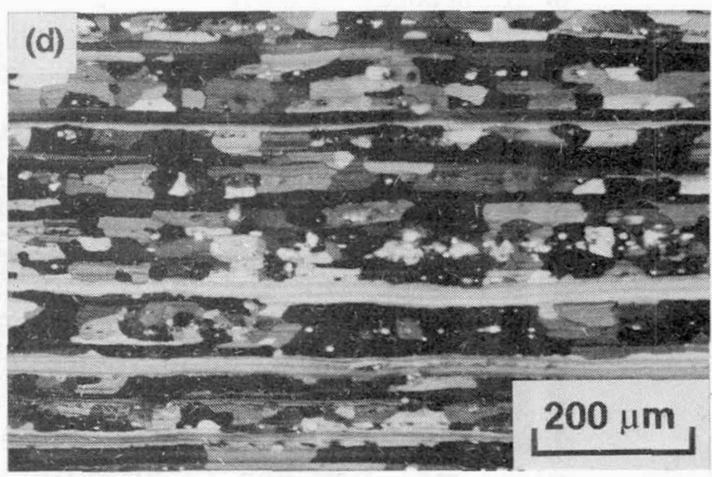

(d) 5182 alloy

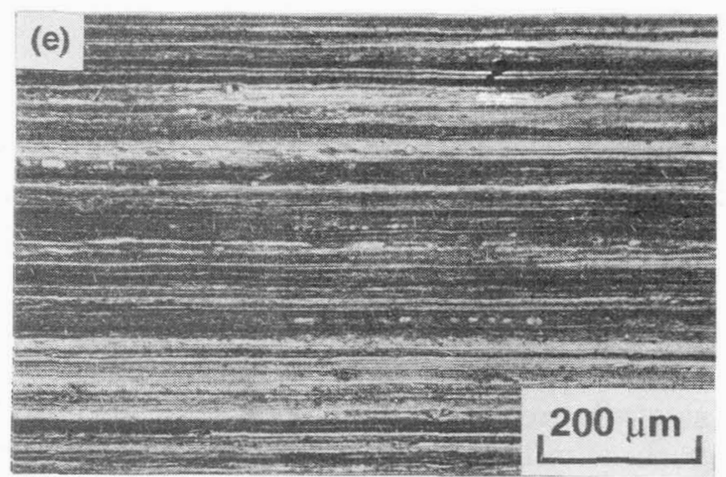

(e) $7 \mathrm{NO1}$ alloy

Fig.1 The optical microstructures for all alloys after annealing 
Low strain rate tensile tests $\left(1 \times 10^{-3} \sim 1 \times 10^{-1} \mathrm{~s}^{-1}\right)$ were performed with an instron machine, and intermediate strain rate tensile tests $\left(1 \times 10^{-1} \sim 3 \times 10^{2} \mathrm{~s}^{-1}\right)$ were performed with the hydraulic tensile testing machine, and the dynamic tensile tests $\left(4 \times 10^{2}\right.$ $\sim 4 \times 10^{3} \mathrm{~s}^{-1}$ ) were performed using a split Hopkinson pressure bar system which incorporates a specific attachment. The incremental strain rate tests were performed by the hydraulic tensile testing machine. This machine has a valve corresponding proportionally to given voltage. Therefore, using a computer with a controlling voltage pattern, the constant strain rate tests or the incremental strain rate tests can be performed.

Table 1 The chemical composition of the commercial aluminum alloys

\begin{tabular}{|c|c|c|c|c|c|c|c|c|c|}
\hline \multirow[b]{2}{*}{ ALLOY } & \multirow[b]{2}{*}{ zn } & \multirow[b]{2}{*}{$\mathbf{u g}$} & \multirow[b]{2}{*}{$\mathrm{Cu}$} & \multicolumn{2}{|c|}{ BLBMBNT } & \multicolumn{2}{|l|}{$(t z)$} & \multirow[b]{2}{*}{$\mathrm{Fe}$} & \multirow[b]{2}{*}{$s \pm$} \\
\hline & & & & $\operatorname{mn}$ & $C r$ & $\mathrm{Zr}$ & $\mathbf{T i}$ & & \\
\hline 1050 & & & & & & & & 0.27 & 0.10 \\
\hline 3003 & & & 0.15 & 1.20 & & & & 0.61 & 0.27 \\
\hline 3004 & & 1.21 & 0.15 & 1.05 & & & & 0.33 & 0.17 \\
\hline 5182 & & 4.52 & & 0.35 & & & 0.03 & 0.25 & 0.10 \\
\hline $7 \mathrm{NOI}$ & 4.50 & 1.71 & 0.15 & 0.35 & 0.16 & 0.15 & 0.05 & 0.21 & 0.12 \\
\hline
\end{tabular}

\section{3-RESULTS AND DISCUSSIONS}

Typical stress-strain curves for all present alloys are shown in Fig.2 (a) (e) for several strain rates respectively. No significant change is observed in the shape of the stressstrain curves. However, a little difference can be observed between the alloys (1050 and 3003 alloy) containing no magnesium atom and the alloys $(3004,5182$ and $7 \mathrm{NO} 1$ alloy) containing magnesium atoms in solute. For the alloys containing no magnesium. the higher the strain rates are the higher the flow stresses in the stress-strain curves. On the other hand, for the alloys containing magnesium atoms in solute, different behaviors can be observed. The higher the strain rates are the higher the flow stresses at an early stage of deformation ( $e<0.05$ ); however, the flow stresses beyond this strain at the intermediate strain rate of $1 \mathrm{~s}^{-1}$ are lower than those in both strain rates below and over this intermediate strain rate.

The serrations have been observed on the load and displacement curves in the strain rate range below $10^{-2} \mathrm{~s}^{-1}$. But, in the strain rate range over $10^{-2} \mathrm{~s}^{-1}$, no serration has been observed. The serrations are caused by the manifestation of strain-aging in some alloys. [4] Therefore, the decreasing of the stress level in this study seems to be caused not only by the strain aging.

Fig.3 shows the relationship between the maximum flow stress (the true stress at the strain which shows maximum load on load-displacement curves) and the strain rate for all present alloys at room temperature. Two types can be observed in the shape of the stress-strain rate curves of these alloys. The maximum flow stress of both 1050 and 3003 alloys increases with strain rate; but the maximum flow stress of 3004,5182 and 7NO1 alloys decreases with increasing strain rate in the range from $10^{-3}$ to $100 \mathrm{~s}^{-1}$. Beyond this strain rate range, the maximum flow stress increases rapidly with strain rate. These three alloys which show the particular behavior of flow stress include magnesium atoms in solute. The degree of reduction in maximum flow stress in both low and intermediate strain rate range increase with increasing the content of $\mathrm{Mg}$. 
Therefore, this behavior of flow stress in these alloys containing magnesium atoms in solute seems to be concerned with an interaction between magnesium atoms in solute and dislocations.

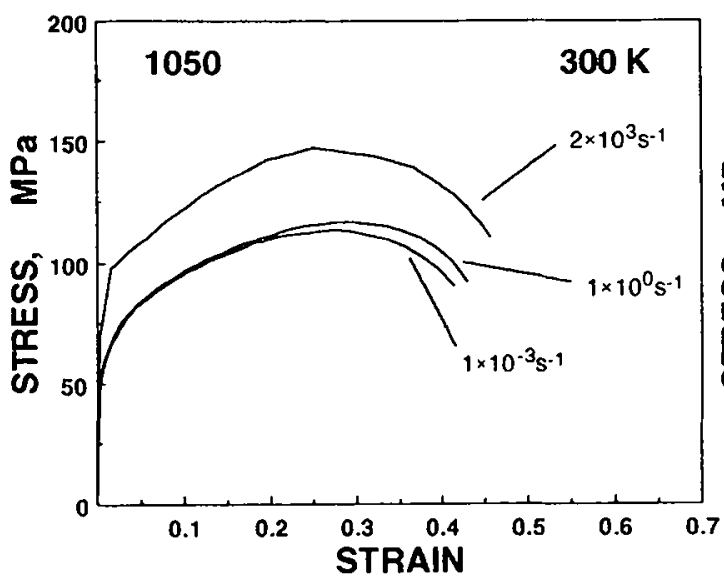

(a) 1050 alloy

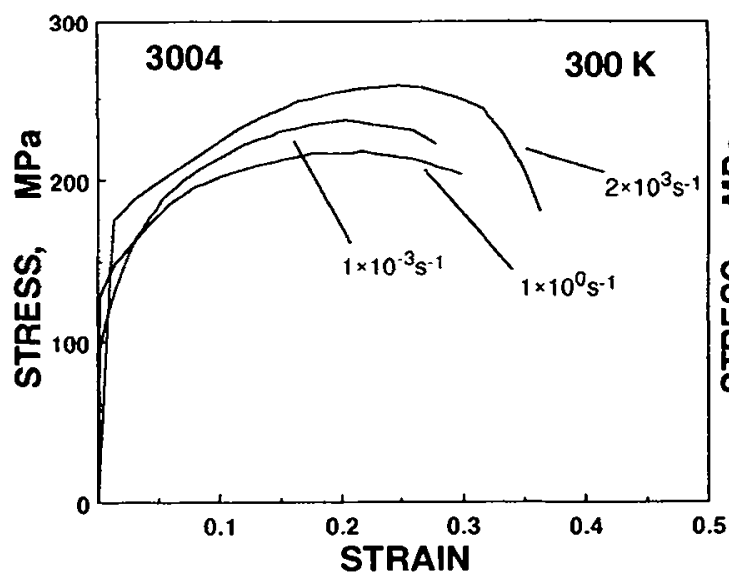

(c) 3004 alloy

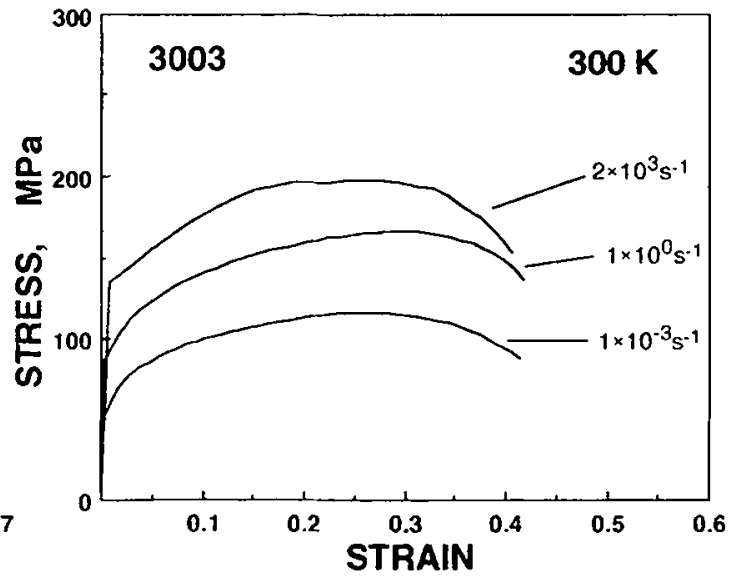

(b) 3003 alloy

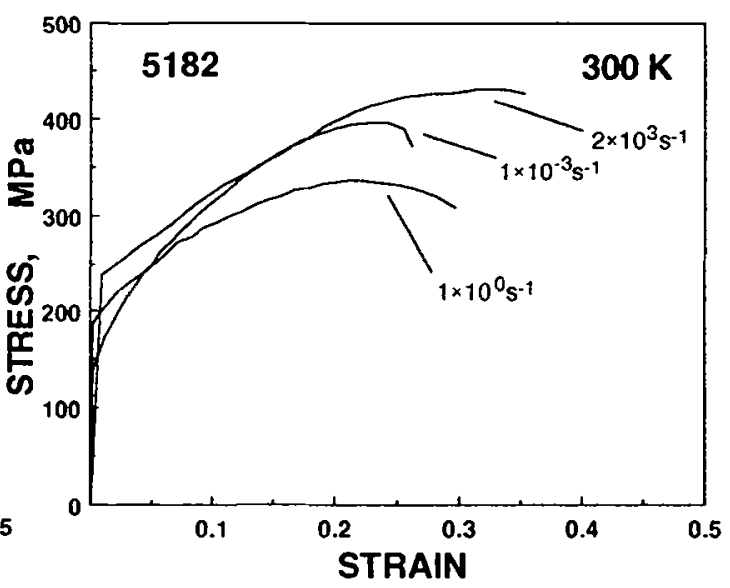

(d) 5182 alloy

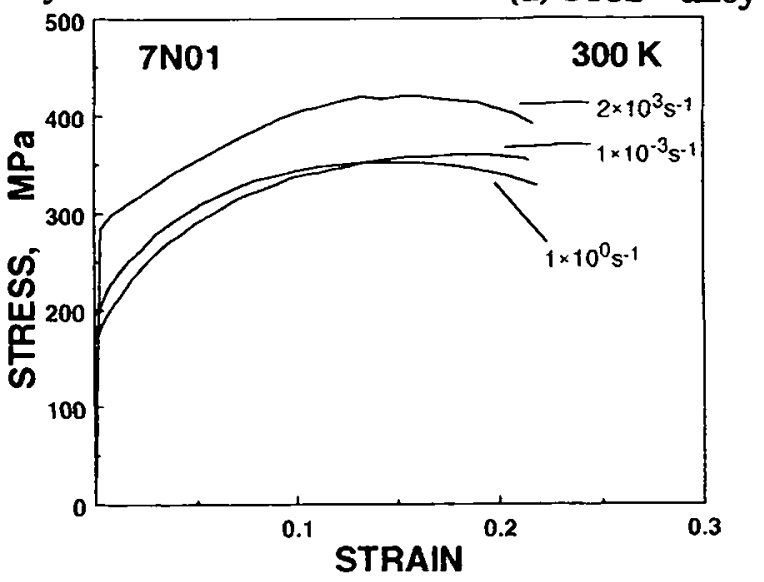

(e) 7NO1 alloy

Fig.2 Typical stress-strain curves for all present alloys 
Fig.4 shows the relationship between the elongations in failure and strain rates. The elongations in fatlure increase with increasing strain rate except for 7NO1 alloy. The increasing ratio of elongation, $r_{e}=E / E_{0}\left(E_{0}\right.$; elongation in failure at the strain rate of $10^{-3} \mathrm{~s}^{-1}, \mathrm{E}$; elongation in fallure at any strain rate) for all alloys was shown in Fig.5 as

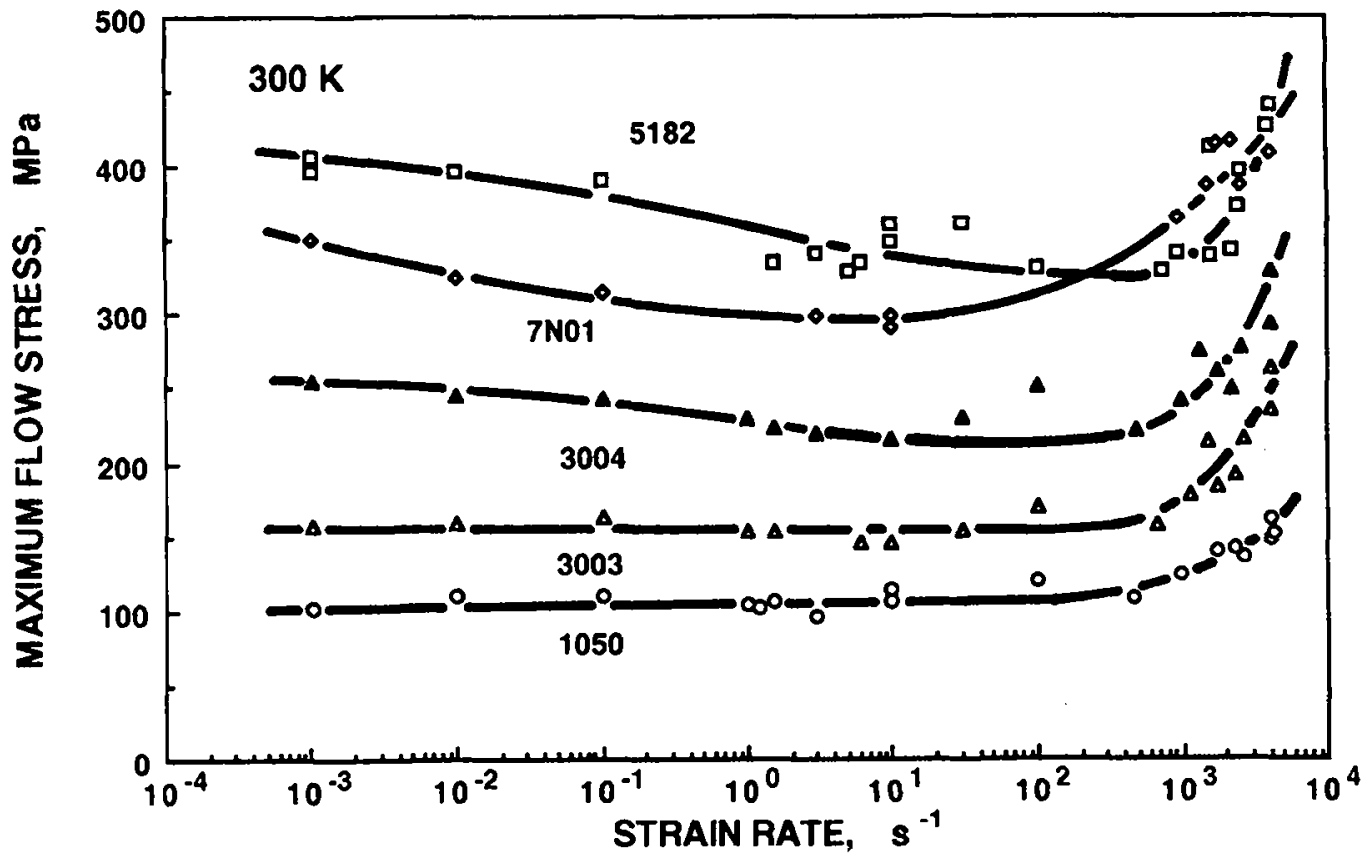

Fig.3 The relationship between the maximum flow stress and the strain rate for all present alloys

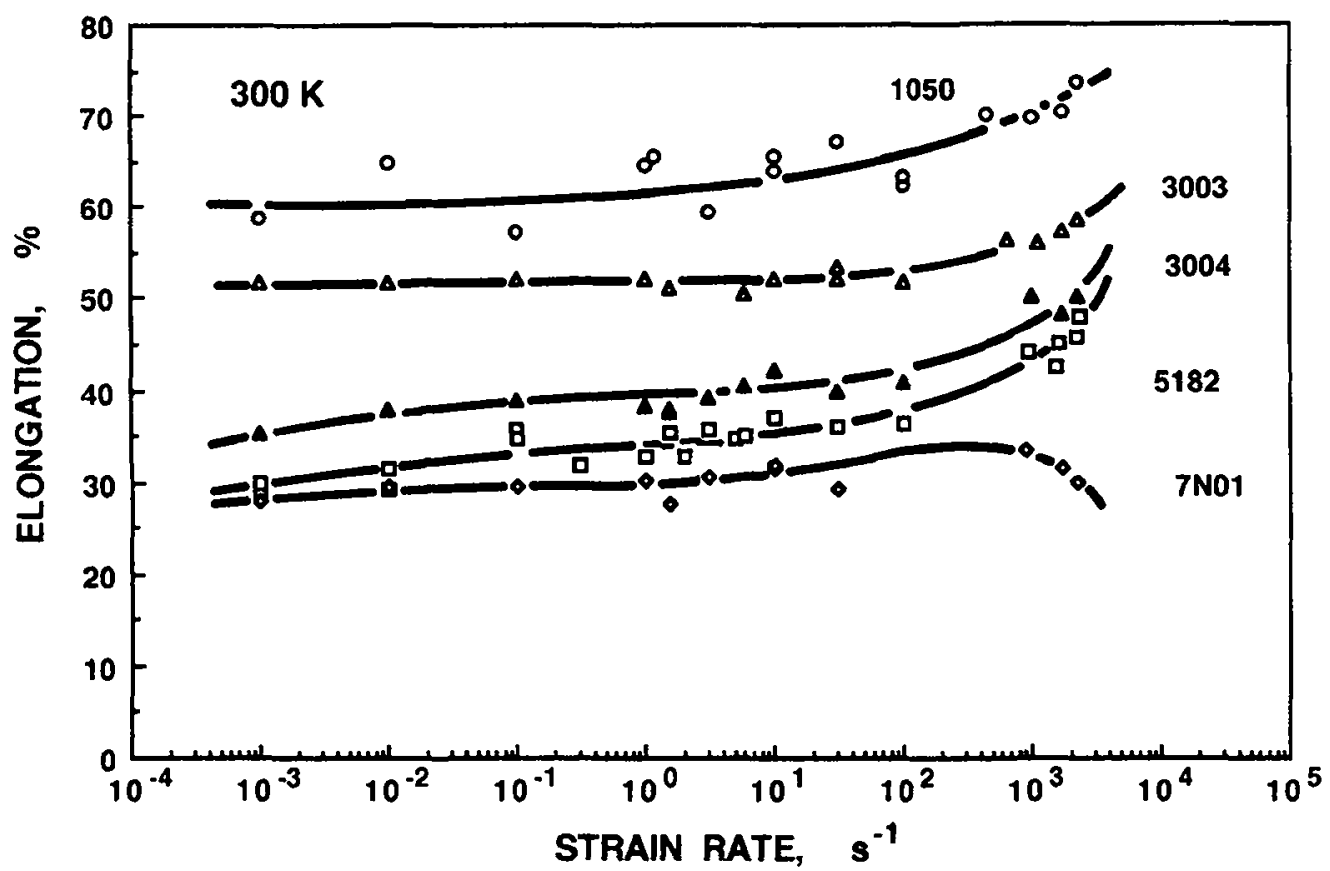

Fig.4 The relationship between the elongations in failure and strain rates 
a function of strain rate. The value of $r_{e}$ increases with strain rate for all alloys except for 7NO1 alloy. In a high strain range over $10^{3} \mathrm{~s}^{-1}$ the larger values of $r_{e}$ were obtained for both 5182 and 3004 alloys. Both alloys contain more magnesium atoms in solute than the other alloys. Therefore, it seems that the more magnesium atoms in solute lead the elongation in fallure increase. Though 7N01 alloy also contains the magnesium atoms in solute, the elongation in failure was not improved to large values at high strain rates. There are many particles in sub-micrometer size along the grain boundaries for $7 \mathrm{NO} 1$ alloy and these particles seem to lead the elongation in failure to a small limited value.

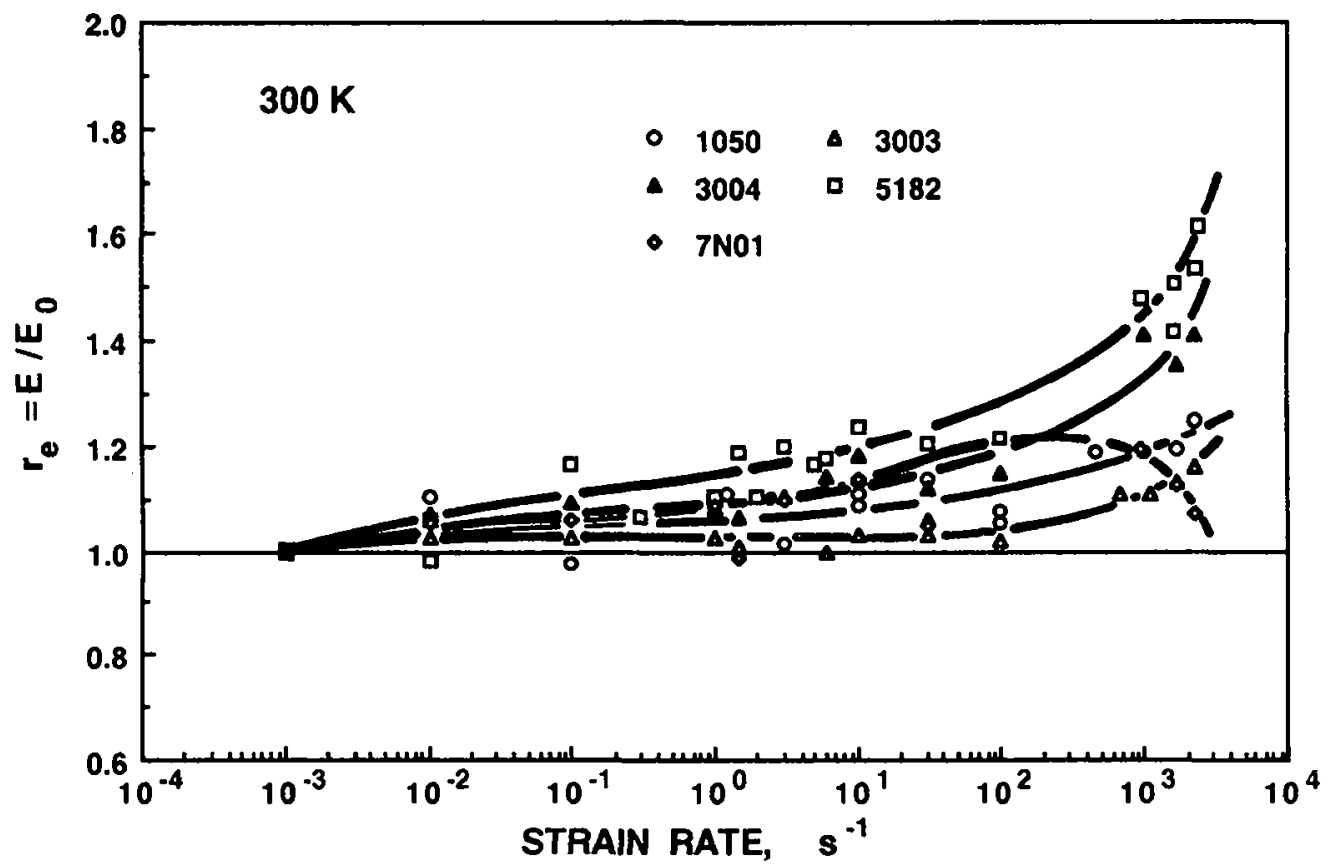

Fig.5 The increasing ratio of elongation, $r_{e}=E / E_{0}$ for all alloys as a function of strain rate

\section{4-SUMMARY}

The general conclusions of strain rate dependence on mechanical properties in some commercial aluminum alloys can be established as follows:

(1) For all the alloys containing magnesium atoms in solute, the maximum flow stresses decrease with increasing strain rates in the range from $10^{-3}$ to $100 \mathrm{~s}^{-1}$. The degree of reduction in maximum flow stress in both low and intermediate strain rate range increase with increasing the content of $\mathrm{Mg}$.

(2) For all present alloy, the elongations in failure increase with increasing strain rate except for $7 \mathrm{NOl}$ alloy.

\section{REFERENCES}

/1/ Kawata,K. and et al. In: High Velocity Deformation of Solids, (K. Kawata \& J.Shioiri, Ed.), Springer Verlag, New York (1978) pp.1.

/2/ Chiem.C.Y., Lee.W.S., and Meyer,P., JOURNAL DE PHYSIQUE, (1988) C3-19.

/3/ Lindholm, U.S., J. Mech. Phys. Sol., 12 (1964) 317-335.

/4/ Nadai, A., "THEORY OF FLOW AND FRACTURE OF SOLIDS", VOLUME ONE, McGRAW-HILL Book COMPANY. Inc. (1950) 313-316. 